\title{
Introduction. Cultural migrants? The consequences of educational mobility and changing social class among first-in-family graduates in Hungary
}

\author{
Judit Durst ${ }^{1}$ - Zsanna Nyírō² \\ https://doi.org/10.51624/SzocSzemle.2021.3.1 \\ Manuscript received: 10 November 2021. \\ Revised manuscript received: 20 November 2021. \\ Acceptance of manuscript for publication: 22 November 2021.
}

The focus of the special issue of these papers is the investigation of the consequences of education-driven upward mobility of first-in-family graduates in Hungary. All papers except one draw on the findings of a 3-year research project that aimed to explore the int as 'first-generation intellectuals ersectional effect of class, race and gender on the outcome and the price of different mobility trajectories of first-generation intellectuals. ${ }^{3}$ They address the question of whether there are significant differences regarding upward educational mobility trajectories and their consequences for academically high achieving Roma and non-Roma men and women. We call our study group academic high achievers or first-in-family graduates - none of whose parents have a degree and who are designated as 'first generation intellectuals' in Hungarian mobility studies (among others Ferenczi 2003, Mazsu 2012).

Our theoretical stance in this project is that upward social mobility cannot be seen as an individual project but needs to be understood and analysed in the wider context of social inequalities. In this sense, scholars of educational sociology like Diane Reay (2018), an academic of working-class background herself, speak about

1 Institute for Minority Studies, Research Centre for Social Sciences, Department of Anthropology, University College London, email: durst.judit@tk.hu

2 Institute for Minority Studies, Research Centre for Social Sciences, email: nyiro.zsanna@tk.hu

3 The research project titled 'Social mobility and Ethnicity: Trajectories, outcomes and hidden costs of educational success' was supported by the Hungarian Academy of Science (NKFHI) research grant (no. K-125 497). Apart from the authors, the research team members were Ábel Bálint Bereményi, Péter Bogdán, Julianna Boros, Fanni Dés, Margit Feischmidt, Ernő Kállai and Attila Papp Z.. We thank them for their valuable and insightful contributions to our thinking on many of the issues raised in this introduction. We are also grateful to Orsolya Udvari, Flóra Hann, Anna Turnai and Hanka Lajos for helping us to code our numerous (165) and voluminous life story interviews which serve as the empirical basis of this thematic issue. A special thank goes to Emily Barosso for her careful and painstaking language editing of all the papers in the special issue. 
the 'cruelty of social mobility'. That is, individual successes of upwardly mobile people occur at the cost of collective failure:

"At the collective level, social mobility is no solution to either educational inequalities or wider social and economic injustices. But at the individual level it is also an inadequate solution, particularly for those of us whose social mobility was driven by a desire to 'put things right' and 'make things better' for the communities we came from and the people we left behind." (Reay 2013: 674)

According to this line of thinking, the promise of social mobility, the concept that 'everyone can be a winner' (Lawler - Payne 2018) is a kind of 'Cruel Optimism' (Reay 2018, drawing on Berlant 2011). Berlant who coined this concept argues that cruel optimism exists when something we desire is, in reality, an obstacle to our flourishing. Cruel optimism "entails the fantasy that our relentless efforts will bring us love, care, intimacy, success, security and well-being even when they are highly unlikely to do so because in doing so we are forming optimistic attachments to the very power structures that have oppressed us, and our families before us. Social mobility is one such optimistic fantasy that ensnares and works on both the individual psyche and collective consciousness." (Reay 2018: 146). Therefore, argues Reay, social mobility is not a cure for social ills, but on the contrary, it can harm both the socially mobile individual and the communities they grew up in. What is more, the promise of social mobility allows highly unequal capitalist societies to justify and maintain social inequalities (Lawler-Payne 2018, Payne 2018, Reay 2018).

In Hungary, some first-generation intellectuals recounted the same cruel and painful personal experience of their own upward mobility trajectories. Among them is Szilárd Borbély, a famous poet and novelist who poignantly writes about his journey from a marginalised, closed peasant village to Budapest, the seat of the capital's literary cultural elite, using the metaphor of a homeless cultural migrant:

"After the death of my father, I had long been thinking of how and when I became a traitor. I believe they consider me a traitor, despite the fact that they incited me to become a traitor. In the beginning when I went home to visit them [my parents], I could easily leave behind the new language and manners that I put on as a disguise in my new life...I talked to them in the old manner, I used the same words, the same tone and put on the same ragged clothes and socks with holes that they did, that I used to do. But after a while, I did not feel at home, and I could only mimic the feeling of belonging to them. I did not recognise it, but they did. And from then on, they started to feel ashamed that they had put on their socks with holes and ragged clothes...Even though I had become a relatively successful migrant, I was [still] a peasant and I stayed a peasant. But according to them, those who betrayed the community of the subjugated and became one of the educated gentlemen [úrak] committed an unforgivable sin...Those who 
leave the village people, betray them...I am a cultural migrant. First-generation migrants do everything to forget their past, their language, the place they left. They have to forget all this to become successful migrants." (Borbély 2013)

Our research findings that we present in this thematic issue resonate with this account. Many of our study participants, especially from socio-economically disadvantaged Roma families voiced their frustration about the 'responbilisation' (Leyton 2020) of individuals as to their success or failure in life. Some recounted how angry it makes them feel when people ask them why if they made it (to get a degree, against the odds), others (from immobile, marginalised Roma communities) could not? Some respond to these questions with a widely accepted phrase, "because a few people can climb Mount Everest, it does not mean that it is not extremely difficult and impossible for many" (see also Pogácsa 2021).

Following this theoretical thread, this issue challenges public dialogue about social mobility in Hungary (such as in many other European countries) that has recently been dominated by the myth of meritocracy ${ }^{4}$. These dialogues use a neo-liberal vocabulary of aspiration, ambition, and choice, considering mobility as an individual project of self-advancement by moving up in social hierarchy (Lawler-Payne 2018). In this discourse social mobility is the new panacea against wider historic and social ills, and the answer to increased classed and racialised inequalities. Instead, this collection of papers deploys the sociological perspectives of social ascension and asks how education-driven upward mobility works, what this mobility means for those experiencing it, and what the consequences of changing social class and traveling long or not so long distances through social space in fact are?

\section{Mainstream and 'marginal' studies of social mobility}

This thematic issue addresses personal experiences of the process of education-driven upward social mobility. Most of the papers explore the way how classed, racialised and gendered past of an individual matters throughout her mobility journey and how and through which mechanisms the destination of the social ascension of the individual is affected. Many of the contributors apply an intersectional lens when explaining the consequences of upward social mobility, be it in the realm of intimate partner relationships (Dés 2021, this volume) or in the case of the divided habitus ${ }^{5}$ (Nyírő-Durst 2021, this volume). This concept (coined by Crenshaw 1991) is helpful in illuminating the overlapping systems of intersecting forms of domination those based on race, gender, class, sexuality, ability and so forth - that affect an

4 We call 'myth of meritocracy' the belief that individual success can be explained by 'merit' alone. (See also Lawler - Payne 2018, Friedman-Laurison 2020).

5 The literature uses several synonymies of Bourdieu's (1999) divided habitus or habitus clivé, such as 'emotional costs' (Reay 2005), or 'emotional imprint' (Freidman 2016) of mobility; 'habitus dislocation' (Christodoulou - Spyridakis 2016) or 'splitting of the self' (Lahire 2011). For a summary see Naudet (2018: 7-10). 
individual's life chances, opportunity structures and social hardships (DesmondEmirbayer 2009).

Our aim is to attempt to expand the scope of mainstream social mobility analysis with 'marginal studies' (Lawler-Payne 2018), that is, our case studies. We agree with Michael Young's (2000) statement that in an ideal view of sociology, we both need surveys and individual experiences when studying social phenomena (see also Friedman-Laurison 2020). "But surveys of random samples were (and are) needed. The individual's experience has to be put into a context to show how far anyone's experience is, in some way, typical or not. Without random samples, one cannot normally generalise about anything; without picking out individuals, the results of the random sampling can be lifeless." 6

By oversimplifying somewhat, we can delineate two major ways of thinking about intergenerational social mobility in mainstream qualitative sociology. Firstly, the most common approach conceives social mobility as a shift from a lower-status profession to a higher one. It is not so much the income derived from the profession but its power and prestige that matters (Goldthorpe 2013, Erikson-Goldthorpe 1992). It takes the labour market as strictly segmented into real professional classes (Loury-Modood-Teles 2005). This globally adopted standard mobility analysis proceeds by aggregating individual occupations into 'big social classes'. Researchers then match people's class origin (in terms of their parent's occupation) with their class destination (in terms of their own occupation) and measure the movement or mobility in between (Friedman-Laurison 2020). This method of creating standard mobility tables makes it possible to do cross-national comparisons and address the question of whether social mobility in a given country is increasing or decreasing.

The second approach, following the same logic, measures intergenerational mobility by comparing the highest educational achievement of parents and their children. This approach presupposes that education is an important vehicle for social mobility through the process of status attainment (Blau-Duncan 1967, Róbert 2001, 2019).

All mainstream social mobility research has traditionally been interested in how open or closed a society is, that is, to what extent people can move or fail to move up or down the social hierarchy (Lawler-Payne 2018). It differentiates between absolute and relative mobility. The absolute mobility rate, in an intergenerational perspective, refers to those whose social position has changed compared to those of their parents. Absolute mobility depends on how far the socio-economic and occupational structure of society changes. If the proportion of different social groups change from one generation to the next, it increases the degree of mobility. Relative mobility measures, on the other hand, provide information on mobility processes while filtering out the effects of structural changes. In this respect, relative measures

6 Michael Young obituary for Peter Willmott in The Guardian, 19 April 2000, cited in Lawler-Payne 2018. 
of mobility are much more suitable to shed light on how and to what extent equality of opportunity has changed in a society, i.e., how much a society can be considered open or closed (Andorka 1982, Bukodi-Goldthorpe 2019, Huszár et al. 2021).

According to the latest mainstream mobility studies in Hungary, both absolute and relative mobility showed a decreasing trend in the period of the last 30 years (Róbert-Bukodi 2004, Róbert 2019, Huszár et al. 2020, 2021). Parallel to other Eastern and Central European countries, Hungarian society typically moved towards closure since the regime change 1989-90 (Jackson-Evans 2017). In the past decade, Hungary even became one among the most closed countries in Europe (cf. Eurofound 2017, OECD 2018, Bukodi-Paskov 2020, Éber 2020). This closure means that the chance of changing one's social position relative to that of her parents is getting smaller and smaller.

Most of the mainstream quantitative social mobility research has a limited conception of time (Friedman-Savage 2018). The standard mobility table compares the origin and destination class of individuals, measuring it in two points in time, and with a single occupation-based variable. The table uses identical classificatory categories for both origin (parent's occupation) and destination (the observed individual's) class. This method is invaluable in offering an exact and internationally comparable way to assess the ratio of how many respondents have moved between classes compared to their parents. It is used to unravel some key features of mobility in the respective countries. However, as Friedman-Laurison (2020) argues, qualitative approaches, outside mainstream mobility analysis can be important and innovative through bringing life into survey data or exploring the workings of hidden mechanisms.

Following this perspective, a relatively new line of social mobility studies investigates personal accounts of upwardly mobile people to understand the diverging outcomes and processes of the different mobility paths. Scholars from this tradition argue that Pierre Bourdieu's conceptual tools offer a great deal of analytical insight into the study of social mobility (e.g. Reay 2005, Friedman 2016, Thatcher et al. 2016, Friedman-Savage 2018, Ingram-Abrahams 2016). According to this argument, Bourdieu's analytical concepts are fruitful because of his habitus concept which connects on both the structural and the individual level; his sensitivity to time and temporality, his interest in (capital) accumulation, his awareness of the cultural and subjective, as well as the structural components of mobility. These analytical tools offer a highly productive way to understand the social trajectories of upward mobility (Freidman-Savage 2018). What is equally important for our purpose here, is that adopting a Bourdieusian perspective allows us a more multidimensional understanding of class position. As Friedman and Laurison (2020) argue, this approach makes it possible to register the resources, or 'capitals' that individuals carry with them on their mobility journey and into their occupations (Nyírö-Durst 2021, Boros-Bogdán-Durst 2021, this volume). It stresses that both the origin and 
the destination of the mobility path can only be fully understood as the sum total of different forms of economic, cultural and social capitals at a person's disposal (Friedman-Savage 2018). Through this Bourdieusian lens, we can unveil the emotional imprint (Friedman 2016) of one's social background, that is, the effect of the 'long shadow of class origin' (Friedman-Laurison 2020) on her mobility trajectory. Our research project on the consequences and outcomes of educationdriven social mobility among Roma and non-Roma first-in-family graduates in Hungary, whose findings this special issue builds on, follows this line of thinking. This long shadow of class origin was succinctly summarised by two of our (majority, non-Roma) first-in-family graduate research participants:

„I can easily recognise the first-generation intellectuals from a distance. They have their shared experience of lack of self-confidence. One can observe on them the constant search for the judgement of their environment. They arrived at a new world, they do not speak it's language, do not know it's cultural codes, it's jokes, and it's references. Therefore they are in constant fear of an imposter-syndrome [of being unveiled as a fraud] ]" (Eszter, 55, founder-director of a charity).

"Even if I have my habilitation, I will always lack the feeling of self-confidence that my colleagues and friends from multigenerational intellectual families from Budapest possess. And it is not only because of the lack of foreign language competency that one needs to acquire to be recognised in our discipline. Even if we consume the same cultural products, go to the same theatre plays, we will never be one of them [the perceived elite]. We were not socialised as part of the elite but we were embedded in a social milieu where we recognised that we are a fighter with a calling. It is only our children who have a chance to accrue selfconfidence... I can see it in my first-generation intellectuals friend circle that many of us tried to get the feeling of 'being at home' as a newcomer in a new world through an unconscious marriage strategy. We married a first-generation partner who comes from the same social background, who understands our world. I do not feel compeer to someone who has travelled the world, plays the piano, and who is full of self-confidence." (Zoltán, 52, research professor).

\section{Social mobility and race/ethnicity}

There is no representative data available about the first-in-family graduates and the changing rates of social mobility in an ethnic dimension, that compares the majority (non-Roma) and minority (Roma) populations in Hungary. However, there are extensive quantitative studies about the disadvantaged situation of Roma in 
education and the discrimination against Roma in the labour market in Hungary (Cf. Hajdu-Kertesi-Kézdi 2014, 2021, Kertesi-Kézdi 2016).

Hajdu-Kertesi-Kézdi (2014) studied the educational situation of Roma students after the regime change. They compared the educational attainment of the cohort born in 1971 with the cohort born around 1991 at the age of 20-21. They identified two trends. On the one hand, there has been a significant catch-up in the successful completion of primary school and further education in secondary school. (The latter typically means vocational school for the Roma children). On the second hand, the gap between Roma and non-Roma students in the case of completing secondary school and participation in higher education has significantly increased.

According to the results of Kertesi and Kézdi (2016), the gap between the educational attainment of Roma and non-Roma students arises at the level of secondary school. Their study analysed the educational achievement of a cohort of students who started secondary school in 2006. They found that $75 \%$ of non-Roma students take a final maturity exam while this rate is only $24 \%$ among Roma students. The college attendance among non-Roma students is $31 \%$ while the corresponding figure for Roma is only 4\%. The broad ethnic gap in higher education has manifested also in the 2011 Census data. Where almost one-fifth of Hungarian people possess a university degree, only 1,2 per cent of Roma have graduated from a higher education institution according to the latest census in 2011 (National Statistical Office 2015).

Kertesi and Kézdi (2016) also found that the disadvantage of Roma students is due to social differences in income, wealth and education of parents, and ethnic factors do not have an important role. The authors identified two mechanisms that are responsible for the ethnic difference in high school attainment. Firstly, Roma children's home environment is less favourable for their cognitive development compared to those of non-Roma children. Secondly, the educational environment of Roma children is lower quality than those of non-Roma children. They also emphasise that the ethnic differences in the home environment of students can be explained by social differences, that is, ethnicity does not play a role in it. The educational environment of Roma children is less favourable because of ethnic segregation. Most of the Roma students study in classrooms where there are many pedagogical problems that makes teaching very difficult. The reason for this selection is residential inequalities, selection by social disadvantage, and ethnic exclusion mechanisms.

Small scale ethnographic data suggests that education-driven upward social mobility chances for Roma have practically stalled in recent decades (Zolnay 2016). Our interviews with leaders of various educational support programmes confirm the tendency of shrinking chances of educational mobility for Roma children and youth from socio-economically disadvantaged family backgrounds. (Cf. Boros-BogdánDurst 2021, this volume). 
Part of the reason for the stalled mobility of the Roma, beyond the abovementioned factors is that the post-socialist transition destroyed most low-skilled workplaces, and resulted in a drastic drop in the employment rates of the loweducated Roma. By the early 1990s, the ethnic employment gap reached 40 percentage points (Kertesi-Kézdi 2005). The deep occupational crisis of the early 1990s likely contributed the most to the intergenerational transmission of disadvantage and poverty (Kertesi-Kézdi 2005), while the political and economic changes following the regime change may have generated greater movements in the upper segments of society (Szelényi -Tóth 2019).

Some of the papers of this special issue argue that among other factors, and on top of the above-mentioned reasons, the social process of 'racial domination' (Desmond-Emirbayer 2009) also contributes to this huge ethnic gap in educational achievement between the Roma and non-Roma in Hungary. Desmond and Emirbayer (2009) delineate two specific manifestations of racial domination: institutional racism and everyday interpersonal racism. As a historically embedded, systematic White domination of People of Colour ${ }^{8}$, institutional racism withholds from People of Colour opportunities, privileges, and rights that many Whites enjoy. ${ }^{9}$ Informed by the workings of institutions, racial domination manifests in everyday interactions and practices too.

In the same line of thinking, critical Whiteness scholars define racism not as individual race prejudice but as encompassing economic, political, social and cultural structures, actions and beliefs that systematize and perpetuate an unequal distribution of privileges, resources and power between White people and People of Colour (DiAngelo 2011, Yosso 2005). This unequal distribution benefits Whites and disadvantages People of Colour overall as a group. Although Whiteness studies were born in the U.S, their structural approach makes the concept of Whiteness a heuristic analytical tool also in the context of Romany Studies, relating to Europe's biggest and most discriminated racialized minority (Kóczé 2020). While previous scholars did not use this particular term in their analysis of the reasons behind the multidimensional disadvantages of the Roma in Hungarian society, they indeed followed the same line of thinking when they shed light on the social process of an 'ethnic ceiling' (Szalai 2014), or "ethnic penalty”, be it in the education sector (Szalai 2014, Kertesi-Kézdi 2016), or on the labour market (Kertesi-Kézdi 2005).

As Nyírő and Durst (2021) explore in this volume, belonging to a racialised (stigmatised and discriminated) Roma minority group has a significant influence on the subjective experience and on the price of upward mobility. Neckerman-

8 Critical race theorists such as Yosso (2005) call 'People of Colour' (or racialized minorities) the visible minority groups who are often stigmatised by race.

9 As Nyírő and Durst (2021, this volume) reminds us, for Whiteness scholars the term 'Whiteness' and 'White' is not to describe a discrete entity (for example, skin colour alone) but to signify a constellation of social processes and practices. It delineates a location of unearned structural advantage, and race privilege (DiAngelo 2011). In this sense, Whiteness as an analytical notion, refers to the specific dimensions of racism that serve to elevate White people over People of Colour. 
Carter-Lee (1999) and Shahrokni (2015) suggest that the persistent salience of discrimination in educational and labour market settings, along with the importance of interclass solidarity with co-ethnic members of one's community of origin, with those who are 'left behind' create unique mobility dilemmas for upwardly mobile, racialised minorities. Being one of the few members of a visible minority in an elite setting also has a psychological cost largely unknown to those from a majority background.

Previous research shows that among academically high-achieving Roma the most common upward mobility trajectory, contrary to the common belief of assimilation, is their distinctive minority mobility path which leads to their selective acculturation into the majority society (Durst-Bereményi 2021). This distinctive incorporation into the mainstream is close to what the related academic scholarship calls the 'minority culture of mobility' (Neckermann-Carter-Lee 1999). The three main elements of this distinct mobility trajectory among the Roma are the followings. Firstly, the construction of a Roma middle-class identity that takes belonging to the Roma community as a source of pride (Kende 2007, Neményi-Vajda 2014), in contrast to the widespread racial stereotypes or Romaphobia (McGarry 2017) in Hungary (and all over Europe) that are closely tied to the perception of Roma as a member of the underclass. Secondly, the creation of grass-roots Roma organizations. Thirdly, the practice of giving back to their people of origin relegate many Roma professionals to a particular segment of the labour market, in jobs to help communities in need. (Nyírő-Durst 2018). This minority mobility trajectory helps the upwardly mobile Roma mitigate the distinctive price of their changing social class and make sense of the hardship of social ascension.

\section{The socioeconomic, educational and labour market characteristics of first-generation graduates in Hungary from a survey perspective}

Previous studies on particular segments of first-generation university students in Hungary commonly found that this group has a disadvantaged position, compared to those students who come from multigenerational college-educated families. They not only lack material capital but are also deficient of the incorporated forms of cultural capital (Ferenczi 2003, Bocsi - Pusztai - Fényes 2020).

In the following, we describe own findings of the target group of this thematic issue: (Roma and non-Roma) first-in-family graduates, and compare them to the total Hungarian graduate population, in terms of only two dimensions of sociodemographic characteristics: that is the choice of study fields in higher education; and the women's number of children. ${ }^{10}$

10 For detailed description of the socio-economic and demographic characteristics of first-in-family graduates in Hungary see Nyírő 2021. 
Data on Roma graduates and the total population of Hungarian graduates have been accessed through the 2011 census, while data about first-generation graduates ${ }^{11}$ has been provided by the 2016 micro census. ${ }^{12}$ We define Roma graduates as having obtained Bachelor's (BA), Master's (MA) or doctoral degrees and having selfidentified as Roma ${ }^{13}$ at the 2011 census. ${ }^{14}$ According to the latest census, the number of graduates was 1440000 in Hungary in 2011, among whom 2424 respondents (1.7 percent) identified as Roma (and Hungarian).

For the purpose of this special issue, this introduction draws attention only to two main findings of our secondary data analysis. Firstly, that at the time of the census in 2011, first-in-family Roma graduates had a distinctive concentration in the field of studies in higher education in humanities and arts. Garaz and Torotcoi (2017) reported similar findings in the case of Roma graduates supported by the Roma Educational Fund in Eastern and Southern Europe).

As Figure 1 shows, Roma graduates significantly deviate from those of the two other groups in the case of three fields of study. While approximately every tenth Roma graduate (11\%) completed their degrees in the humanities and arts, the same ratio is less than $5 \%$ among first-generation graduates and the total graduate population. Roma graduates are overrepresented in subjects related to health and social care (11\%) compared to first-generation graduates (7\%) and the total graduate population (8\%). The most striking differences are in the fields of technical, industrial and construction training: only $10 \%$ of Roma graduates completed degrees in this field, in contrast to a fifth of first-generation graduates (19\%) and $17 \%$ of the total graduate population.

11 Those respondents are regarded as first-generation graduates who are 20-years-old or older and have obtained a university degree and completed the supplementary "Social stratification" questionnaire in the 2016 micro census, having indicated that both of their parents' highest educational attainment is lower than Bachelor's degree (BA).

12 As the 2011 census does not contain questions regarding parents' educational attainment, data concerning first-generation graduates has been complemented via the 2016 micro census. However, this data is not sufficient to compare first-generation graduates and first-generation Roma graduates. Although the questionnaire did include data on first-generation graduates by nationality, due to the low number of first-generation Roma graduates (as the unweighted data suggests), the dataset is not representative of this population. Therefore, the two databases were used together to characterise the studied populations.

13 The Central Statistical Office used several questions for nationality self-identification in the 2011 census besides nationality itself, such as questions regarding mother tongue or the language spoken among family members/friends. Previous academic findings suggest that the self-identification of multiple nationalities and identities is more easily grasped by two or more, equally important questions. Accordingly, the Central Statistical Office uses four questions to determine respondents' nationalities. If a respondent indicated a nationality in at least one of the four questions, they were considered as selfidentifying with that nationality (besides Hungarian). Source: Central Statistical Office (2011) http://www.ksh.hu/nepszamlalas/ docs/modszertan.pdf

14 As mentioned above, there is no available data regarding first-generation Roma graduates, therefore this research is limited to the features of the Roma graduate population. However, based on the results of a previous qualitative research among 53 participants (Durst-Fejös-Nyírö 2014) and a study on 124 Roma higher education students participating in advanced colleges (Lukács 2018), we assume that the majority of Roma graduates are first-generation graduates. Thus, and given the lack of more comprehensive data, statistical interpretations regarding Roma graduates in general are presumed to be representative of first-generation Roma graduates. 
Figure 1. Distribution of the total graduate population, first-generation graduates and Roma graduates by field of study, by percentage

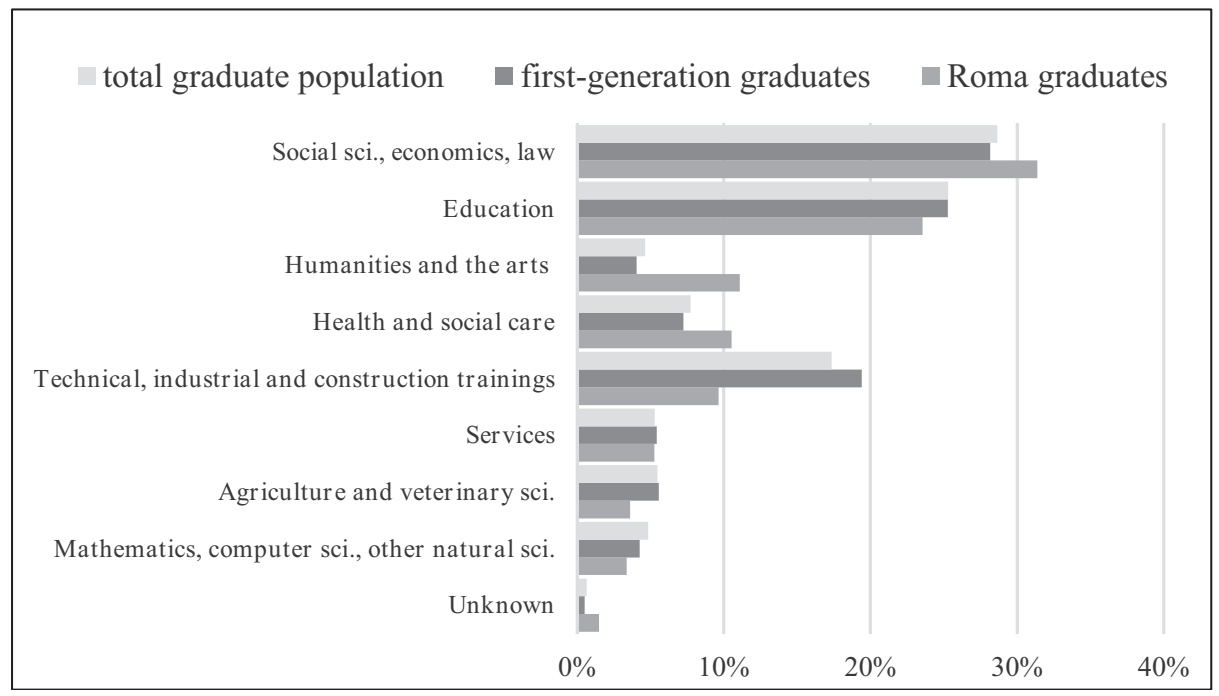

Source: Central Statistical Office, 2011 census, 2016 micro census, own calculation

The distribution of the most popular fields of study - Social Sciences, Economics, and Law - by specialisation shows that the distribution of Roma graduates and first-generation graduates differs significantly in the case of several specialisations, too More than a third of first-generation graduates attained their highest level of education in Economics (35\%), while only a fifth (19\%) of Roma graduates studied in this field. The fields of Sociology and Cultural Studies, as well as political and civil society studies are overrepresented among Roma graduates ( $16 \%$ and $9 \%$ accordingly) compared to first-generation graduates ( $7 \%$ and $3 \%$ accordingly). Contrastingly, ratio of the fields of finance, banking and insurance is considerably higher among first-generation graduates (8\%) than among Roma graduates (4\%). (Figure 2) 
Figure 2. Distribution of first-generation graduates and Roma graduates in the field of social sciences, economics and law by specialization, by percentage

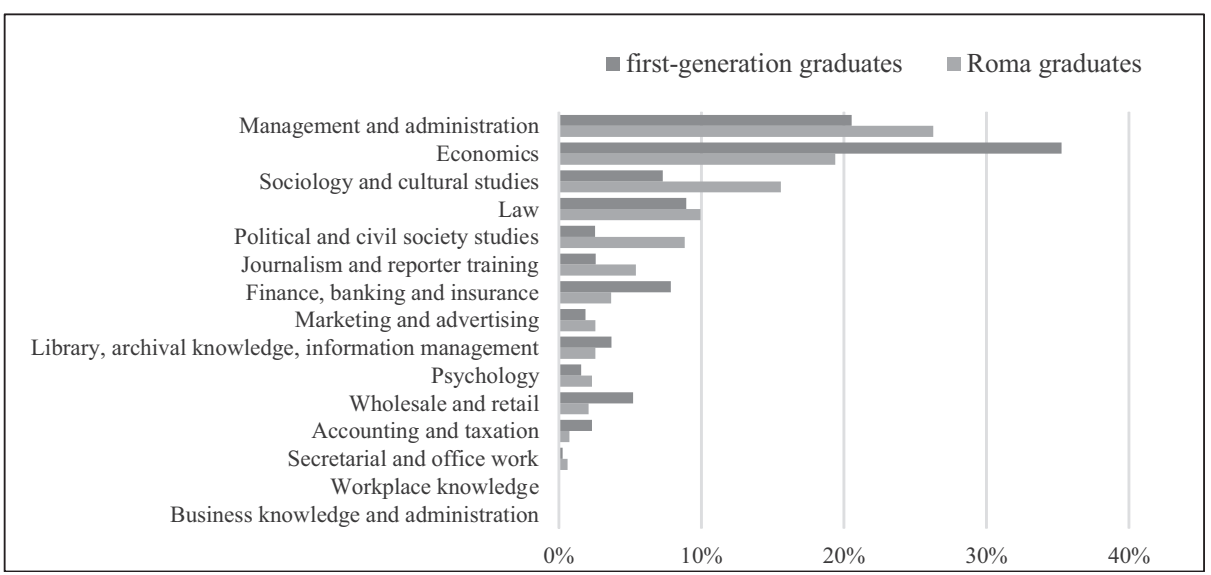

Source: Central Statistical Office, 2011 census, 2016 micro census, own calculation

Secondly, we found a significant difference in the ratio of childless women among Roma and the total female first-in-family graduates. The percentage of childless women is highest among Roma graduates (41\%), with significantly lower rates of childlessness in the total female graduate population (34\%) and among firstgeneration graduates (28\%). This finding resonates with our empirical result based on the interviews with the study participants that one of the 'hidden costs of upward mobility' (Cole-Omari 2003) for first-in-family Roma graduate women is the difficulty of selecting a partner with whom they can start a family (see Dés 2021, this volume and also Durst-Fejős-Nyírő 2016).

\section{Layout of the thematic issue}

Nyírő and Durst study how upward mobility through education and the movement between social worlds affect the habitus. They reveal the most important factors that contribute to the destabilization of the habitus by using narrative interviews with first-in-family Roma and non-Roma graduates. The paper emphasizes the intersectional effect of class and race/ethnicity on the subjective experience of upward mobility. It also explains why class origins matter more in some areas of the labour market than others.

Dés illustrates how structural inequalities appear in interpersonal relationships and how the costs of social mobility influence intimate partner relationships between individuals. By using narrative interviews with Roma and non-Roma women, she demonstrates the consequences of upward mobility via education on 
partner selection and maintaining a relationship. The article reveals why Roma origin and upward social mobility make it difficult to find a desired partner, why upwardly mobile women often feel that they are in a 'no man's land' in the context of intimate relationships, and how the conflict between expected gender roles and their ambitions influence their relationships.

Boros, Bogdán and Durst provide a critical discussion on the mainstream interpretation of the Bourdieusian cultural capital as white (mainstream, nonRoma) middle-class cultural resource. Instead, they show that one of the main contributions of the Roma educational support programs pertaining to the social mobility of the Roma is that they have been creating Roma (non-white) cultural capital for their mentees. In their interpretation, Roma cultural capital is a set of resources that middle-class, upwardly mobile Roma youth can deploy to make meaning of their Roma identities, recast it, in order to forge networks of belonging and counter their marginal status, given Hungary's racialized power relations. Through this, Roma educational support programs that offer a complex approach, contribute hugely to mitigate the price of their mentee's upward mobility.

Bereményi and Durst examine the self-narratives of first-generation collegeeducated and highly resilient Roma women focusing on their meaning-making and social navigation processes through their mobility journey. They identify the resilient mobility trajectory when the 'emotional cost' of upward mobility is minimal and describe the role of social and physical ecology in the process of resilience.

Papp Z . and Zsigmond study the consequences of educational upward mobility on different areas of life among minority Hungarians living in neighbouring countries by using a survey methodology. In order to reveal the outcomes of mobility, the authors compare first-generation graduates to multigenerational graduates in the field of social and cultural reproduction, integration into the university, organisational and community life, political attitudes and identity politics.

\section{References}

Abrahams, J. - Ingram, N. (2016): Stepping outside of oneself: how a cleft-habitus can lead to greater reflexivity through occupying 'the third space'. In: Thatcher, J. - Ingram, N. - Burke, C., - Abrahams, J. (eds.) Bourdieu: The Next Generation: The development of Bourdieu's intellectual heritage in contemporary UK sociology, 168-184. https://doi.org/10.4324/9781315693415

Andorka, R. (1982): A társadalmi mobilitás változásai Magyarországon. Budapest: Gondolat

Bereményi, B. Á. - Durst, J. (2021): Meaning making and resilience among academically high- achieving Roma women. Szociológiai Szemle, 31(3), 103-131. https://doi.org/10.51624/SzocSzemle.2021.3.5

Berlant, L. (2011): Cruel Optimism. Durham, NC: Duke University Press 
Blau, P.M. - Duncan, O.D. (1967): The American Occupational Structure. New York: Wiley

Bocsi, V. - Pusztai, G. - Fényes, Zs. H. (2020): Elsőgenerációs hallgatók a campuson. Különös tekintettel az eredményesség kérdéskörére. Szociológiai Szemle, 30(4): 26-44. https://doi.org/10.51624/SzocSzemle.2020.4.2

Borbély, Sz. (2013): Egy elveszett nyelv. Élet és Irodalom, julius 5. www.es.hu

Boros, J. - Bogdán, P. - Durst, J. (2021): Accumulating Roma cultural capital: Firstin-family graduates and the role of educational talent support programs in Hungary in mitigating the price of social mobility. Szociológiai Szemle, 31(3), 74102. https://doi.org/10.51624/SzocSzemle.2021.3.4

Bourdieu, P. (1999): The Weight of the World. Social Suffering in Contemporary Society. Cambridge: Polity.

Bukodi, E. - Goldthorpe (2019): Social mobility and education in Britain. Cambridge: Cambridge University Press.

Bukodi, E. - M. Paskov (2020): Intergenerational Class Mobility among Men and Women in Europe. European Sociological Review, 36(4): 495-512.

https://doi.org/10.1093/esr/jcaa001

Christodoulou, M. - Spyridakis, M. (2016): Upwardly mobile working-class adolescents: a biographical approach on habitus dislocation. Cambridge Journal of Education. 47(3): 315-335. https://doi.org/10.1080/0305764X.2016.1161729

Cole, E. - R. Omari, S. R. (2003): Race, Class and the Dilemmas of Upward Mobility for African Americans. Journal of Social Issues, 59 (4): 785-802.

Crenshaw, K. (1991): Mapping the margins: Intersectionality, identity politics, and violence against women of color. Stanford Law Review, 43(6): 1241-1299.

Desmond, M. - Emirbayer, M. (2009): What is racial domination? Du Bois Review, 6(2): 335-355. https://doi.org/10.1017/S10742058X09990166

Dés, F. (2021): Costs of Social Mobility in the Context of Intimate Partner Relationships. "It is really easy to be angry at someone who is front of me and not at the system, which produces the inequalities between us". Szociológiai Szemle, 31(3), 51-73. https://doi.org/10.51624/SzocSzemle.2021.3.3

Di Angelo, R. (2011): White Fragility. International Journal of Critical Pedagogy. 3(3): 54-70.

Durst, J.- Fejős, A.- Nyírő, Zs. (2016): “Másoknak ez munka, nekem szívügyem”. $\mathrm{Az}$ etnicitás szerepe a diplomás roma nők munka- család konstrukcióinak alakulásában. Socio.hu, 2: 198- 225.

Durst, J. - Bereményi, Á. (2021): "I Felt I Arrived Home”: The Minority Trajectory of Mobility for First-in-Family Hungarian Roma Graduates. Social and Economic Vulnerability of Roma People, 229-248.

https://doi.org/10.1007/978-3-030-52588-0_14

Erikson, R. - Goldthorpe, J.H. (1992): The constant flux: A study of class mobility in industrial societies. New York: Oxford University Press.

Eurofound (2017): Social mobility in the EU. Luxembourg: European Union 
Éber (2020): A csepp. A félperifériás magyar társadalom osztályszerkezete. Budapest: Napvilág Kiadó

Ferenczi, Z. (2003): Az elsőgenerációs értelmiség kialakulásának sajátosságai. Statisztikai Szemle, 81(12): 1073- 1089.

Friedman, S. (2016): Habitus Clive and the Emotional Imprint of Social Mobility. The Sociological Review. 64(1): 129-147. https://doi.org/10.1111/1467-954X.12280

Friedman, S. - Savage, M. (2018): Time, accumulation and trajectory: Bourdieu and social mobility. In: Lawler, S. - Payne, G. (eds): Social Mobility for the 21st Century. Everyone a Winner? London and New York: Routledge: 67-79

Friedman, S. - Laurison, D. (2020): The class ceiling: Why it pays to be privileged. Bristol: Policy Press University of Bristol. https://doi.org/10.2307/j.ctv5zftbj

Garaz, S. - Torotcoi, S. (2017): Increasing Access to Higher Education and the Reproduction of Social Inequalities: The Case of Roma University Students in Eastern and Southeastern Europe. European Education, 49:10-35.

https://doi.org/10.1080/10564934.2017.1280334

Goldthorpe, J. H. (2013): Understanding - and Misunderstanding - Social Mobility in Britain. Journal of Social Policy, 42(3): 431-50.

Hajdu, T. - Kertesi, G. - Kézdi, G. (2014): Roma fiatalok a középiskolában: Beszámoló a Tárki Életpálya-felvételének 2006 és 2012 közötti hullámaiból (No. BWP-2014/7). Budapest Working Papers on the Labour Market.

Hajdu, T. - Kertesi, G. - Kézdi, G. (2021): Ethnic Segregation and Inter-Ethnic Relationships in Hungarian Schools. ON_EDUCATION: JOURNAL FOR RESEARCH AND DEBATE. 4(11): 1-6.

Huszár, Á. - Balogh K. - Győri Á. (2020): A társadalmi mobilitás egyenlőtlensége a nők és a férfiak között. In Kovách, I. (eds.) Mobilitás és integráció a magyar társadalomban. Budapest: Argumentum, 35-57.

Huszár, Á. - Balogh K. - Győri Á. (2021): Intergenerational Class Mobility in Hungary, 1973-2018. Unpublished manuscript

Ingram, N. - Abrahams, J. (2016): Stepping outside of oneself: how a cleft-habitus can lead to greater reflexivity through occupying the 'third space'. In Thatcher, J.-Ingram, N.-Burke, C.-Abrahams, J. (eds): Bourdieu: The Next Generation. The development of Bourdieu's intellectual heritage in contemporary UK sociology. Sociological Futures. London and New York: Routledge: 140-156.

Jackson, M. - Evans, G. (2017): Rebuilding Walls. Sociological Science, 4:54-79.

Kende, A. (2007): 'Success Stories? Roma University Students Overcoming Social Exclusion in Hungary'. In H. Colley (ed): Social Inclusion for Young People: Breaking Down the Barriers. Strasbourg: Council of Europe, 133-144.

Kertesi, G. - Kézdi, G. (2005) Foglalkoztatási válság gyermekei. In Kertesi, G. (eds.) A társadalom peremén. Budapest: Osiris, 247-312.

Kertesi, G. - Kézdi, G (2016): A roma fiatalok esélyei és az iskolarendszer egyenlőtlensége (No. BWP-2016/3). Budapest Working Papers on the Labour Market. 
Kóczé, A. (2020): Racialization, Racial Oppression of Roma. In: Ness, I. - Cope, Z. (eds): The Palgrave Encyclopedia of Imperialism and Anti-Imperialism. Palgrave Macmillan. https://doi.org/10.1007/978-3-319-91206-6_124-1

Lahire, B. (2011): The Plural Actor. Cambridge: Polity Press.

Lawler, S. - Payne, G. (2018): Introduction. Everyone a winner? In: Lawler, S. Payne, G. (eds): Social Mobility for the $21^{\text {st }}$ century. Everyone a winner? London and New York: Routledge. https://doi.org/10.4324/9781351996808

Leyton, D. (2020): The European Discourse of Inclusion Policies for Roma in Higher Education: Racialized Neoliberal Governmentality in Semi-Peripheral Europe. In Morley, L. - Mirga, A. - Redzepi, N. (eds): The Roma in European Higher Education. Recasting identities, Re-Imagining Futures. London - New York: Bloomsbury Academic, 57-75.

Loury, G. C. - Modood, T. - Teles, S. M. (2005): Introduction. In Loury, G. C. - Modood, T. - Teles, S. M. (ed.): Ethnicity, Social Mobility, and Public Policy: Comparing the USA and UK. Cambridge (UK): Cambridge University Press.

Lukács, J.Á. (2018): Roma egyetemisták beilleszkedési mintázatai kapcsolathálózati megközelítésben. Doktori tézisek. Semmelweis Egyetem Mentális Egészségtudományok Doktori Iskola

Mazsu, J. (2012): Tanulmányok a magyar értelmiség társadalomtörténetéhez 1825 1914. Budapest: Gondolat

McGarry, A. (2017): Romaphobia: The Last Acceptable Form of Racism. Zed Books

Naudet, J. (2018): Stepping into the elite: Trajectories of social achievement in India, France, and the United States. Oxford University Press.

Neckerman, K.- Carter, P.- Lee, J. (1999): Segmented assimilation and minority cultures of mobility. Ethnic and Racial Studies, 22(6): 945- 965.

Neményi, M. - Vajda, R. (2014): Intricacies of Ethnicity: A Comparative Study of Minority Identity Formation during Adolescence. In Szalai, J. - Schiff, C. (eds.): Migrant, Roma and Post-Colonial Youth in Education across Europe. Being 'Visibly' Different. Palgrave Macmillan, 103-119.

Nyírő, Zs. (2021): The effect of educational mobility on habitus. Budapest: Corvinus University, Doctoral School of Sociology.

Nyírő, Zs. - Durst, J. (2018): Soul work and giving back: Ethnic support groups and the hidden costs of social mobility. Lessons from Hungarian Roma graduates. INTERSECTIONS: EAST EUROPEAN JOURNAL OF SOCIETY AND POLITICS. 4 (1):88-108. https://doi.org/10.17356/ieejsp.v4i1.406

Nyírô, Zs. - Durst, J. (2021): Racialization rules: The effect of educational upward mobility on habitus. Szociológiai Szemle, 31(3), 21-50.

https://doi.org/10.51624/SzocSzemle.2021.3.2

OECD (2018): A Broken Social Elevator? Paris: OECD. 
Papp Z. A. - Zsigmond, Cs. (2021): Floating freely? Hungarian first- and multigenerational young intellectuals across the border. Szociológiai Szemle, 31(3), 132157. https://doi.org/10.51624/SzocSzemle.2021.3.6

Payne, G. (2018): Which ways now? In Lawler, S. - Payne, G. (eds): Social Mobility for the $21^{\text {st }}$ century. Everyone a winner? London and New York: Routledge.

Pogácsa, Z. (2021): Viselkedésgazdaságtan: a szegények gazdálkodása. Pogi Podcast 38. 31 July open. spotify.com

Reay, D. (2005): Beyond consciousness? The psychic landscape of social class. Sociology. 39(5): 911-928. https://doi.org/10.1177/0038038505058372

Reay, D. (2013): Social mobility, a panacea for austere times: Tales of emperors, frogs, and tadpoles. British Journal of Sociology of Education, Special Issue on Social Mobility, 34(5-6): 660-677.

Reay, D. (2018): The cruelty of social mobility. Individual success at the cost of collective failure. In Lawler, S. - Payne, G. (eds): Social Mobility for the 21st century. Everyone a winner? London and New York: Routledge.

Róbert, P. (2001): Hipotézisek az oktatás és a társadalmi mobilitás összefüggéseiről. In: Róbert, P.: Társadalmi mobilitás. A tények és a vélemények tükrében. Budapest: Andorka Rudolf Társadalomtudományi Társaság - Századvég Kiadó: 47- 56.

Róbert, P. (2019) Intergenerational educational mobility in European societies before and after the crisis. In Tóth, I. G. (ed.): Hungarian Social Report. Budapest: Tárki Társadalomkutatási Intézet Zrt., 120-136.

Róbert, P. - Bukodi, E. (2004): Changes in Intergenerational Class Mobility in Hungary, 1973- 2000. In: Breen, R (ed): Social Mobility in Europe. Oxford: Oxford University Press, 287- 315.

Shahrokni, S. (2015): The minority culture of mobility of France's upwardly mobile descendants of North African immigrants. Ethnic and Racial Studies, 38(7): 10501066.

Szalai, J. (2014): The Emerging 'Ethnic Ceiling': Implications of Grading on Adolescents' Educational Advancement in Comparative Perspective. In: Szalai, J. - Schiff, C. (eds) Migrant, Roma and Post-Colonial Youth in Education across Europe. Palgrave Macmillan, London. https://doi.org/10.1057/9781137308634_5

Szelényi, I. - Tóth I. Gy. (2019): Bezáródás és fluiditás a magyar társadalom szerkezetében. In: Szelényi, I. (eds): Tanulmányok az illiberális posztkommunista kapitalizmusról. Budapest: Corvina: 120-141.

Thatcher, J. - Ingram, N. - Burke, C. - Abrahams, J. (eds) (2016): Bourdieu: The Next Generation. The development of Bourdieu's intellectual heritage in contemporary UK sociology. Sociological Futures. London and New York: Routledge: 88-106.

Zolnay, J. (2016): Kasztosodó közoktatás, kasztosodó társadalom. Esély. Vol.6

Yosso, T. J. (2005). Whose culture has capital? A critical race theory discussion of community cultural wealth. Race ethnicity and education. 8 (1):69-91.

https://doi.org/10.1080/1361332052000341006 